AKRUAL 4 (2) (2013): 139-154 e-ISSN: 2502-6380

AKRUAL

Jurnal Akuntansi

http://fe.unesa.ac.id/ojs/index.php/akrl

\title{
PENGARUH REPUTASI AUDITOR, PREDIKSI KEBANGKRUTAN, DISCLOSURE DAN LEVERAGE TERHADAP PENERIMAAN OPINI AUDIT GOING CONCERN
}

\author{
Eko Budi Santoso \\ Universitas Ciputra \\ E-mail: esantoso@ ciputra.ac.id \\ Ivan Yudhistira Wiyono \\ Universitas Kristen Duta Wacana \\ Artikel diterima: 12 Desember 2012 \\ Terakhir direvisi: 20 Januari 2013
}

\begin{abstract}
Going concern opinion is accepted by a company represents the condition and events which arises auditor's hesitation of the company's going concern. Going concern audit opinion used as early warning to the user of financial statements in order to prevent mistakes on decision making. This study objective was to reinvestigate factors that influencing going concern audit opinion. The factors used on this research are auditor reputation, bankruptcy prediction, disclosure and leverage.

Samples were collected with purposive sampling method and obtained 229 observation data of listed manufacture companies that meet the criteria from year 2009-2011. Logistic regression was been used for hypothesis testing. The result showed that bankruptcy prediction using Z-score model and leverage affected acceptance going concern audit opinion. The hypothesis testing also showed that auditor reputation and disclosure did not affect acceptance going concern audit opinion.
\end{abstract}

Keywords: Going concern opinion, auditor reputation, bankruptcy prediction, disclosure, leverage.

\section{PENDAHULUAN}

Krisis keuangan global yang terjadi tahun 2008 lalu telah memberikan dampak buruk bagi perekonomian dunia. Krisis yang berasal dari Amerika Serikat ini membawa dampak yang luar biasa terhadap perekonomian dan sistem keuangan semua negara di dunia tak terkecuali di Indonesia. Krisis ini ditandai dengan bangkrutnya salah satu bank investasi terbesar di Amerika Serikat, Lehman Brothers. Keberadaan entitas bisnis telah banyak diwarnai oleh kasus hukum yang melibatkan manipulasi akuntansi. Sebelum peristiwa bangkrutnya Lehman Brothers, peristiwa serupa pernah terjadi pada beberapa perusahaan besar di Amerika seperti Enron dan 
WorldCom. Keberadaan entitas bisnis merupakan ciri dari sebuah lingkungan ekonomi yang dalam jangka panjang bertujuan untuk mempertahankan kelangsungan hidup (going concern). Kelangsungan hidup suatu usaha selalu dihubungkan dengan kemampuan manajemen dalam mengelola entitas agar bertahan hidup.

Kelangsungan hidup (going concern) adalah kemampuan perusahaan dalam mempertahankan kelangsungan hidupnya. Suatu entitas bisnis dalam menjalankan usahanya tidak hanya menghasilkan keuntungan seoptimal mungkin, tetapi juga bertujuan menjaga kelangsungan hidupnya. Opini kelangsungan hidup (going concern) merupakan opini yang dikeluarkan auditor untuk memastikan apakah perusahaan dapat mempertahankan kelangsungan hidupnya (SPAP, 2001). Opini auditor atas laporan keuangan juga menjadi salah satu bahan pertimbangan bagi para investor dalam membuat keputusan berinvestasi. Auditor bertanggung jawab mengevaluasi apakah terdapat kesangsian besar terhadap kemampuan entitas dalam mempertahankan kelangsungan hidupnya. Auditor dapat mengidentifikasi informasi mengenai kondisi atau peristiwa tertentu yang menunjukkan adanya kesangsian besar tentang kemampuan entitas dalam mempertahankan kelangsungan hidupnya dalam jangka waktu pantas, yaitu tidak lebih dari satu tahun sejak tanggal laporan keuangan yang sedang diaudit (IAI, 2001:seksi 341).

Secara umum, beberapa hal yang dapat mempengaruhi auditor dalam menerbitkan opini audit going concern (IAI, 2001: seksi 341.3, paragraf 6) antara lain: Tren negatif, petunjuk lain tentang kemungkinan kesulitan keuangan perusahaan, masalah intern, dan masalah luar yang terjadi. Weiss (2002) dalam Pratama dan Badera (2009) menemukan bahwa dari 288 perusahaan publik yang mengalami kebangkrutan, Enron dan 95 perusahaan lainnya menerima opini wajar tanpa pengecualian pada tahun sebelum terjadinya kebangkrutan. Fakta ini menunjukan bahwa tidak sedikit dari auditor yang gagal dalam memberikan opini going concern kepada auditee, yaitu keadaan dimana perusahaan yang tidak sehat namun menerima pendapat wajar tanpa pengecualian (unqualified). Hal ini menyebabkan tingkat kepercayaan masyarakat terhadap profesi auditor jadi menurun.

Permasalahan going concern seharusnya diberikan oleh auditor dan dimasukan dalam opini auditnya pada saat opini audit tersebut akan diterbitkan. Laporan audit penting sekali dalam suatu audit karena laporan audit menginformasikan pemakai informasi mengenai apa yang dilakukan auditor dan kesimpulan yang diperolehnya. Tujuan utama auditor menyusun laporan audit adalah untuk memperoleh dan mengevaluasi tentang laporan-laporan entitas dengan maksud agar dapat memberikan pendapat apakah laporan-laporan tersebut telah disajikan secara wajar sesuai dengan kriteria yang telah ditetapkan, yaitu prinsip-prinsip akuntansi yang berlaku umum (GAAP).

Terdapat faktor-faktor yang mempengaruhi penerimaan opini audit going concern. Pada penelitian ini, peneliti menggunakan variabel independen reputasi auditor, prediksi kebangkrutan, Disclosure dan leverage dengan sampel penelitian perusahaan manufaktur yang terdaftar di Bursa Efek Indonesia periode 2009-2011. 
Penelitian ini mengacu pada penelitian Setyarno dkk. (2006); Santosa dan Wedari (2007); Pratama dan Badera (2009); Susanto (2010); dan Junaidi dan Hartono (2010).

\section{KAJIAN PUSTAKA \& PENGEMBANGAN HIPOTESIS Opini Audit Going Concern}

Going Concern adalah kelangsungan hidup suatu usaha. Opini audit going concern adalah opini yang dikeluarkan oleh auditor untuk mengevaluasi apakah ada kesangsian tentang kemampuan perusahaan untuk mempertahankan kelangsungan hidupnya (IAI, 2001: seksi 341). Laporan audit dengan modifikasi mengenai going concern merupakan suatu indikasi bahwa dalam penilaian auditor terdapat risiko auditee tidak dapat bertahan dalam bisnis. Keputusan auditor dalam memberikan opini audit going concern melibatkan beberapa pertimbangan. Auditor harus mempertimbangkan hasil dari operasi, kondisi ekonomi yang mempengaruhi perusahaan, kemampuan membayar hutang dan kebutuhan likuiditas di masa yang akan datang.

Secara umum, beberapa hal yang dapat mempengaruhi auditor dalam menerbitkan opini audit going concern (IAI, 2001: seksi 341.3 paragraf 6) antara lain:

1. Tren negatif, sebagai contoh: Kerugian operasi yang terjadi berulang, kekurangan modal kerja, arus kas yang negatif, rasio keuangan yang tidak baik.

2. Petunjuk lain tentang kemungkinan kesulitan keuangan perusahaan, sebagai contoh : Kegagalan dalam memenuhi kewajiban, penunggakan pembayaran dividen, penjualan sebagian besar aktiva.

3. Masalah intern, sebagai contoh: Pemogokan tenaga kerja, ketergantungan besar atas kesuksesan proyek tertentu, komitmen jangka panjang yang bersifat tidak ekonomis, kebutuhan untuk memperbaiki operasi.

4. Masalah luar yang terjadi, sebagai contoh : Pengaduan gugatan pengadilan, keluarnya undang-undang atau masalah lain yang kemungkinan membahayakan kemampuan entitas untuk beroperasi, kehilangan pemasok atau pelanggan, kerugian akibat bencana alam.

IAI (2001: seksi 341.2) memberikan pedoman kepada auditor tentang dampak kemampuan satuan usaha dalam mempertahankan kelangsungan hidupnya terhadap opini auditor sebagai berikut:

1. Auditor mempertimbangkan apakah hasil prosedur yang dilaksanakan dalam perencanaan, pengumpulan bukti audit untuk berbagai tujuan audit, dan penyelesaian auditnya, dapat mengidentifikasi keadaan atau peristiwa yang secara keseluruhan menunjukan adanya kesangsian besar mengenai kemampuan perusahaan dalam mempertahankan kelangsungan hidupnya dalam jangka waktu pantas. Mungkin diperlukan untuk memperoleh informasi tambahan mengenai kondisi dan peristiwa beserta bukti-bukti yang mendukung informasi yang mengurangi kesangsian auditor. 
2. Jika auditor yakin bahwa terdapat kesangsian mengenai kemampuan perusahaan dalam mempertahankan kelangsungan hidupnya dalam jangka waktu pantas, auditor harus:

a. Memperoleh informasi mengenai rencana manajemen yang ditujukan untuk mengurangi dampak kondisi dan peristiwa tersebut.

b. Menetapkan kemungkinan bahwa rencana tersebut secara efektif dilaksanakan.

3. Setelah auditor mengevaluasi rencana manajemen, ia mengambil kesimpulan apakah ia masih memiliki kesangsian besar mengenai kemampuan perusahaan dalam mempertahankan kelangsungan hidupnya dalam jangka waktu yang pantas.

\section{Pengembangan Hipotesis}

De Angelo (1981) dalam Santosa dan Wedari (2007) menyatakan bahwa auditor skala besar memiliki insentif yang lebih untuk menghindari kritikas kerusakan reputasi dari pada auditor skala kecil. Auditor skala besar juga lebih cenderung mengungkapkan masalah-masalah yang ada karena mereka lebih kuat menghadapi resiko proses peradilan. Argumen tersebut berarti bahwa auditor skala besar memiliki kemungkinan atau dorongan yang lebih untuk melaporkan masalah going concern kliennya apabila terbukti klien terdapat masalah untuk melangsungkan usahanya dibandingkan dengan auditor skala kecil. Mutchler (1986) dalam Fanny dan Saputra (2005) menggunakan proksi skala kantor akuntan publik untuk variabel reputasi kantor akuntan publik untuk melihat kecenderungan opini audit yang diberikan kepada perusahaan yang bermasalah. McKinley et al. (1985) dalam Fanny dan Saputra (2005) menyatakan ketika sebuah kantor akuntan publik mengklaim dirinya sebagai KAP besar seperti yang dilakukan The Big Four, maka mereka akan berusaha keras untuk menjaga nama besar tersebut. Mereka menghindari tindakan-tindakan yang dapat mengganggu nama baik mereka.

\section{$\mathrm{H}_{1}$ : Reputasi Auditor berpengaruh terhadap penerimaan opini audit going concern.}

Kondisi keuangan perusahaan merupakan kondisi dimana keuangan perusahaan dalam keadaan tidak sehat atau krisis. Kondisi keuangan perusahaan biasanya dinilai dengan menggunakan nilai Z-score. Nilai Z-score biasanya digunakan untuk melihat potensi financial distress (kebangkrutan) pada perusahaan. Kebangkrutan sendiri biasanya diartikan sebagai suatu keadaan dimana perusahaan gagal atau tidak mampu lagi memenuhi kewajiban-kewajiban karena perusahaan mengalami kekurangan dana untuk menjalankan atau melanjutkan usahanya.

Altaman dan McGough (1974) dalam Fanny dan Saputra (2005) menemukan bahwa tingkat prediksi kebangkrutan dengan menggunakan suatu model prediksi mencapai tingkat keakuratan $82 \%$ dan menyarankan penggunaan model prediksi kebangkrutan sebagai alat bantu auditor untuk memutuskan kemampuan perusahaan 
mempertahankan kelangsungan hidupnya. Penelitian yang dilakukan oleh Setyarno dkk. (2006) juga berhasil membuktikan bahwa model prediksi kebangkrutan Altman berpengaruh terhadap penerimaan opini audit going concern. Hal ini menunjukan bahwa perusahaan yang terancam bangkrut berpeluang mendapatkan opini audit going concern dari auditor.

Sampai dengan saat ini, Z-score model ini masih lebih banyak digunakan oleh para peneliti, praktisi, serta para akademis di bidang akuntansi dibandingkan model prediksi kebangkrutan lainnya. Penggunaan model Altman yang pertama ini juga didukung oleh penelitian yang dilakukan oleh Ramadhani dan Niki (2009) yang meneliti penggunaan ke-3 model Altman terhadap perusahaan manufaktur di Indonesia. Dan hasil penelitiannya adalah model Altman pertama lah yang paling efektif digunakan untuk perusahaan manufaktur di Indonesia. Z-score yang dikembangkan Altman tersebut selain dapat digunakan untuk menentukan kecenderungan kebangkrutan juga dapat digunakan sebagai ukuran dari keseluruhan kinerja keuangan perusahaan. Hal yang menarik mengenai Z-score adalah keandalannya sebagai alat analisis tanpa memperhatikan bagaimana ukuran perusahaan. Meskipun seandainya perusahaan sangat makmur, bila Z-score mulai turun dengan tajam, maka menunjukan adanya indikasi bahwa perusahaan harus waspada terhadap kebangkrutan. Atau, bila perusahaan baru saja survive, Z-score bisa digunakan untuk membantu mengevaluasi dampak yang telah diperhitungkan dari perubahan upaya-upaya manajemen perusahaan.

\section{$\mathrm{H}_{2}$ : Prediksi kebangkrutan berpengaruh terhadap penerimaan opini audit going concern.}

Pengungkapan informasi (disclosure) dalam laporan keuangan dilakukan untuk melindungi hak pemegang saham yang cenderung terabaikan akibat terpisahnya pihak manajemen yang mengelola perusahaan dan pemegang saham yang memiliki modal. Informasi dalam laporan keuangan harus disajikan dengan memadai untuk memungkinkan dilakukanya sebuah prediksi kondisi keuangan, arus kas dan profitabilitas perusahaan di masa depan. Menurut Valetta (2005) dalam Anwar (2010), diharapkan dengan semakin transparan informasi yang disajikan oleh suatu perusahaan ditambah dengan semakin nyatanya penerapan tata kelola yang baik akan meningkatkan keberhasilan bisnis dalam dunia usaha secara berkesinambungan, juga dapat digunakan untuk memahami bisnis pada suatu perusahaan.

SAS 160 menunjukan bahwa auditor harus memeriksa konsistensi informasi yang diungkapkan dengan indikator keuangan perusahaan, seperti ditunjukan oleh rasio keuangan. Keterbukaan informasi termasuk fakta bahwa perusahaan sedang menghadapi kesulitan keuangan dan bahwa manajemen mencoba untuk memecahkan masalah. Dye (1991) dalam Junaidi dan Hartono (2010) menyatakan bahwa pengungkapan informasi tersebut dapat membantu dalam memberikan gambaran yang lebih jelas tentang kegiatan perusahaan dan dengan demikian dapat mengurangi konflik antara investor dan manajemen 
Lennox (2002) menyebutkan bahwa, pemimpin perusahaan lebih sering tidak mengungkapkan informasi bad news mengenai perusahaan ketika auditor memberikan opini unqualified. Krishnan dan Zhang (2005) dalam Junaidi dan Hartono (2010) berpendapat bahwa, disclosure yang memadai atas informasi laporan keuangan dapat mengurangi litigation risk. Dalam penelitiannya, mereka menemukan bukti bahwa perusahaan yang melakukan pengungkapan sesuai dengan standar pengungkapan cenderung menerima clean opinion. Junaidi dan Hartono (2010) dalam penelitiannya menemukan bukti bahwa disclosure berpengaruh signifikan terhadap dikeluarkannya opini going concern oleh auditor.

\section{$\mathrm{H}_{3}$ : Disclosure berpengaruh terhadap penerimaan opini audit going concern.}

Leverage menurut Sartono (2001) dalam Widyantari (2011) menunjukkan proporsi atas penggunaan utang untuk membiayai investasinya. Leverage dapat diproksikan dengan debt ratio, yaitu membandingkan antara total kewajiban dengan total aktiva. Rasio ini mengukur tingkat persentase utang perusahaan terhadap total aktiva yang dimiliki atau seberapa besar tingkat persentase total aktiva dibiayai dengan utang. Perusahaan yang baik semestinya memiliki komposisi modal yang lebih besar dari hutang. Ukuran ini berhubungan dengan keberadaan dan tidaknya suatu persetujuan hutang. Perusahaan yang tidak mempunyai leverage berarti perusahaan tersebut hanya menggunakan modal sendiri untuk membiayai investasinya, salah satunya untuk pembelian aktiva. Sebaliknya, semakin besar rasio leverage, berarti semakin tinggi nilai utang perusahaan. Atau dengan kata lain, semakin tinggi rasio ini, menunjukan bahwa semakin besar pula investasi yang didanai dari pinjaman. Konsekuensi yang ditimbulkan adalah membesarnya beban bunga yang harus dibayar kepada kreditur.

Semakin besar tingkat rasio leverage menyebabkan timbulnya keraguan akan kemampuan perusahaan untuk mempertahankan kelangsungan usahanya di masa depan, karena sebagian besar dana yang diperoleh perusahaan akan digunakan untuk membiayai utang dan dana untuk beroperasi akan semakin berkurang. Kreditor pada umumnya lebih menyukai debt ratio yang rendah karena kreditor akan mempertimbangkan lebih dahulu kondisi perusahaan dilihat dari rasio hutangnya sebelum memberikan pinjaman. Semakin besar debt ratio akan menyebabkan keraguan atas kemampuan perusahaan dalam melangsungkan hidupnya, juga memperbesar kemungkinan auditor untuk memberikan opini going concern dalam laporan auditor independen.

\section{$\mathrm{H}_{4}$ : Leverage berpengaruh terhadap penerimaan opini audit going concern.}

\section{METODE PENELITIAN}

Pemilihan Sampel

Sampel penelitian ini dipilih menggunakan pendekatan purposive sampling, artinya sampel yang digunakan dalam penelitian ini adalah sampel yang memenuhi kriteria tertentu. Tujuan penggunaan metode ini adalah untuk mendapatkan sampel 
yang representatif. Kriteria-kriteria yang digunakan dalam pengambilan sampel adalah sebagai berikut

1. Perusahaan Manufaktur yang terdaftar di BEI periode 2009-2011.

2. Menerbitkan Laporan Keuangan dalam rupiah.

3. Terdapat Catatan Atas Laporan Keuangan.

4. Terdapat Laporan Auditor Independen.

\section{Definisi Variabel dan Pengukurannya Opini Audit Going Concern}

Opini Going Concern merupakan opini audit modifikasi yang dalam pertimbangan auditor terdapat ketidakpastian atau ketidakmampuan perusahaan dalam mempertahankan kelangsungan hidup perusahaan dalam menjalankan operasinya (SPAP, 2001). Untuk mengukur variabel ini, digunakan variabel dummy. Yaitu sampel yang mendapatkan opini going concern diberi kode 1, sedangkan yang tidak diberi kode 0 .

\section{Reputasi Auditor}

Variabel ini diukur menggunakan variabel dummy. Dimana KAP yang mengaudit laporan keuangan dinilai berdasarkan reputasi KAP tersebut. KAP yang termasuk The Big Four akan diberi kode 1, sedangkan yang non Big Four diberi kode 0 .

\section{Prediksi Kebangkrutan}

Model prediksi kebangkrutan yang terkenal dengan $Z$ score merupakan suatu model yang dikembangkan oleh Altman untuk mendeteksi kebangkrutan suatu perusahaan. Altman (1982) menemukan bahwa tingkat prediksi kebangkrutan dengan menggunakan model yang dikembangkannya mencapai tingkat keakuratan $82 \%$ dan menyarankan penggunaan model tersebut sebagai alat bantu auditor untuk memutuskan kemampuan perusahaan dalam mempertahankan kelangsungan hidupnya. Model Altman yang digunakan dalam penelitian ini adalah:

$$
\mathrm{Z}=1.2 \mathrm{Z1}+1.4 \mathrm{Z2}+3.3 \mathrm{Z3}+\mathbf{0 . 6 Z 4}+\mathbf{0 . 9 9 9 Z 5}
$$

Dimana:

$\mathrm{Z1}=$ Working capital/total asset

$\mathrm{Z2}=$ Retained earnings/total asset

Z3 = Earnings before interest and taxes/total asset

Z4 = Market capitalization/book value of debt

$\mathrm{Z5}=$ Sales/total asset

Berdasarkan analisis ini apabila nilai $\mathrm{Z}$ dari perusahaan yang diteliti lebih kecil dari 1,8 berisiko tinggi terhadap kebangkrutan, bila nilai $\mathrm{Z}$ berada diantara 1,81 sampai dengan 2,99 dikatakan masih memiliki risiko kebangkrutan dan bila di atas 2,99, perusahaan tersebut aman dari kebangkrutan (Hanafi dan Halim, 2007). 


\section{Disclosure}

Disclosure merupakan pengungkapan atas informasi yang diberikan sebagai lampiran pada laporan keuangan dalam bentuk catatan tambahan. Variabel ini diukur dengan menggunakan indeks, dimana peneliti melihat tingkat pengungkapan atas informasi keuangan perusahaan dibandingkan dengan jumlah yang seharusnya diungkapkan oleh perusahaan sesuai dengan peraturan BAPEPAM SE/02/PM/2002, yaitu sebanyak 287 item.

\section{Leverage}

Leverage menunjukkan proporsi atas penggunaan utang untuk membiayai investasinya. Leverage dalam penelitian ini diukur dengan menggunakan debt ratio, yaitu membandingkan antara total kewajiban dengan total aktiva. Rasio ini mengukur sejauh mana aktiva perusahaan dibelanjai dengan kewajiban yang berasal dari kreditor dan modal sendiri yang berasal dari pemegang saham.

$$
\text { Debt Ratio }=\frac{\text { Total Kewajiban }}{\text { Total Aktiva }}
$$

\section{Model Penelitian}

Keterangan:

$$
G C O=\alpha+\beta_{1} R e p+\beta_{2} Z s c o r e+\beta_{3} \text { Discl }+\beta_{4} L e v+e
$$

$\mathrm{GCO}=$ Opini Audit Going Concern

Rep $=$ Reputasi

Zscore $=$ Prediksi Kebangkrutan

Discl $=$ Disclosure

Lev $=$ Leverage

\section{Metode Analisis Data}

Pengujian hipotesis menggunakan analisis regresi logistik karena dalam penelitian ini variabel dependen diukur menggunakan variabel dummy, sehingga peneliti memilih menggunakan alat uji tersebut untuk mengetahui pengaruh dari 4 variabel independen, yaitu reputasi auditor, prediksi kebangkrutan, disclosure dan leverage. Adapun langkah-langkah pengujiannya adalah sebagai berikut:

1. Menilai Kelayakan Model Regresi

Kelayakan model regresi dinilai menggunakan Hosmer and Lemeshow's

Goodness of Fit Test. Jika nilai statistik Hosmer and Lemeshow's Goodness of

Fit Test lebih besar dari 0,05 maka hipotesis nol tidak dapat ditolak dan berarti model mampu memprediksi nilai obeservasinya atau dapat dikatakan model dapat diterima karena sesuai dengan data observasinya (Ghozali, 2005)

2. Menilai Model Fit

Adanya pengurangan nilai antara -2LL awal dengan nilai -2LL akhir menunjukan bahwa model yang dihipotesiskan fit dengan data (Ghozali, 2005) 


\section{Koefisien Regresi (Nagelkerke R Square)}

Besarnya nilai koefisien determinasi pada model regresi logistik ditunjukan dengan nilai Nagelkerke R Square. Nilai Nagelkerke R Square menunjukan variabilitas variabel dependen yang dapat dijelaskan oleh variabilitas variabel independen, sedangkan sisanya dijelaskan oleh variabel-variabel di luar model penelitian.

4. Tabel Klasifikasi

Tabel klasifikasi menunjukan kekuatan prediksi dari model regresi untuk memprediksi kemungkinan terjadinya variabel terikat. Kekuatan prediksi dari model regresi untuk memprediksi kemungkinan terjadinya variabel terikat dalam persen.

5. Estimasi Parameter dan Interpretasinya

Estimasi parameter dilihat melalui koefisien regresi. Koefisien regresi dari tiap variabel-variabel yang diuji menunjukan hubungan antara variabel. Pengujian hipotesis dilakukan dengan cara membandingkan antara nilai probabilitas (sig) dengan tingkat signifikansi $(\alpha)$

\section{HASIL DAN PEMBAHASAN \\ Deskripsi Obyek Penelitian}

Populasi dalam penelitian ini adalah perusahaan manufaktur yang listing di Bursa Efek Indonesia (BEI) pada tahun 2009 sampai 2011. Sampel yang digunakan dalam penelitian ini dipilih dengan metode purposive sampling, sehingga sampel yang didapat merupakan representasi dari populasi sampel yang ada serta sesuai dengan tujuan dari penelitian. Berdasarkan proses seleksi sampel diperoleh sampel akhir 96 perusahaan dengan 237 observasi. Proses seleksi sampel berdasarkan kriteria yang telah ditetapkan ditampilkan pada lampiran 1. Kemudian dilakukan uji outlier dan diperoleh sampel akhirnya 229 observasi. Statistik deskriptif disajikan pada lampiran 2.

\section{Analisis Data}

\section{Menilai Kelayakan Model Regresi}

Kelayakan model regresi dinilai dengan menggunakan Hosmer and Lemeshow's Goodness of Fit Test. Hosmer and Lemeshow's Goodness of Fit Test menguji hipotesis nol bahwa data empiris cocok atau sesuai dengan model (tidak ada perbedaan antara model dengan data sehingga model dapat dikatakan fit). Nilai statistik Hosmer and Lemeshow's Goodness of Fit Test adalah 0.319 dengan probabilitas signifikansi 1.00 yang nilainya jauh di atas 0.05 . Dengan demikian dapat disimpulkan bahwa model mampu memprediksi nilai observasinya atau dapat dikatakan model dapat diterima karena cocok dengan data observasinya. Hasil Hosmer and Lemeshow's Goodness of Fit Test dapat dilihat pada tabel lampiran 3. 


\section{Menilai Keseluruhan Model}

Hasil pengujian menunjukan perbandingan nilai -2 Log Likehood (-2LL) pada awal (Block Number $=0)$ dengan nilai -2LL akhir $($ Block Number $=1)$. Nilai -2LL awal adalah sebesar 195.841. Setelah dimasukan keempat variabel independen, nilai 2LL akhir mengalami penurunan menjadi sebesar 20.733. Penurunan -2 Log Likehood ini menunjukan bahwa model regresi yang lebih baik atau dengan kata lain model yang dihipotesiskan fit dengan data. Hasil pengujian tersebut dapat dilihat pada lampiran 4.

\section{Koefisien Determinasi (Nagelkerke $R$ Square)}

Dilihat dari hasil output pengolahan data, nilai Nagelkerke $R$ Square sebesar 0.930 yang berarti variabilitas dependen yang dapat dijelaskan oleh variabel independen adalah sebesar 93\% sedangkan sisanya sebesar 7\% dijelaskan oleh variabel-variabel lain diluar model penelitian. Dengan kata lain, secara bersama-sama variasi variabel bebas (Reputasi, Prediksi Kebangkrutan, Disclosure dan Leverage) dapat menjelaskan variasi variabel opini audit going concern sebesar 93\%. Hasil pengujian dapat dilihat pada lampiran 5 .

\section{Tabel Klasifikasi}

Dilihat dari hasil pengujian tersebut menunjukan kekuatan prediksi dari model regresi untuk memprediksi kemungkinan perusahaan menerima opini audit going concern adalah sebesar $91.4 \%$. Hal ini menunjukan bahwa dengan model regresi tersebut, terdapat sebanyak 32 sampel perusahaan (91.4\%) yang diprediksi menerima opini audit going concern dari total 35 sampel perusahaan yang menerima opini audit going concern. Kekuatan prediksi dari model regresi untuk memprediksi kemungkinan sampel perusahaan menerima opini audit non going concern adalah sebesar 99\%. Hal ini berarti bahwa dengan model regresi tersebut, terdapat sebanyak 192 sampel perusahaan (99\%) yang diprediksi menerima opini audit non going concern dari total 194 sampel perusahaan yang menerima opini audit non going concern. Hasil pengujian dapat dilihat pada lampiran 6.

\section{Hasil Uji Hipotesis dan Pembahasan}

Pengujian hipotesis dengan model regresi logistik dapat dilihat pada lampiran 4, yaitu tabel Variables in the Equation pada kolom signifikan dibandingkan dengan nilai signifikansi $(\alpha)$ yang digunakan, yaitu $0.05(5 \%)$. Apabila tingkat signifikansi $<$ 0.05, maka H1 diterima, jika tingkat signifikan >0.05, maka H1 tidak dapat diterima.

Reputasi auditor pada lampiran 5 menunjukan koefisien positif sebesar 3.254 dengan tingkat signifikansi 0.106 yang berarti H1 ditolak. Dengan demikian reputasi auditor tidak berpengaruh terhadap penerimaan opini audit going concern. Hal ini dikarenakan baik KAP yang berafiliasi dengan The Big 4 ataupun tidak, mereka mempunyai kode etik dimana mereka harus bersikap independen dan objektif dalam melakukan pekerjaanya. Hasil ini sesuai dengan temuan Chen dan Church (1992) dalam Susanto (2010) dan Setyarno, dkk (2006). 
Prediksi kebangkrutan (Zscore) pada lampiran 5 menunjukan koefisien negatif sebesar 2.495 dengan tingkat signifikansi 0.007 yang berarti $<0.05(\alpha)$. Dengan demikian $\mathrm{H} 2$ diterima, prediksi kebangkrutan berpengaruh terhadap penerimaan opini audit going concern. Semakin rendah nilai Zscore perusahaan akan memperbesar keraguan auditor akan kelangsungan hidup perusahaan, sehingga akan semakin memperbesar kemungkinan auditor untuk mengeluarkan opini going concern terhadap perusahaan. Hasil penelitian ini didukung penelitian yang Sentosa (2007).

Disclosure pada lampiran 5 menunjukan koefisien positif sebesar 10.001 dengan tingkat signifikansi 0.152 yang berarti > 0.05. Dengan demikian H3 ditolak. Disclosure tidak berpengaruh terhadap penerimaan opini audit going concern. Hal ini dikarenakan pengungkapan informasi yang dilakukan baik perusahaan yang mendapatkan opini going concern maupun opini non going concern tidak jauh berbeda. Sehingga disclosure tidak dapat dijadikan pertimbangan auditor dalam menerbitkan opini going concern. Hasil penelitian ini sesuai dengan penelitian yang dilakukan Sari (2011).

Leverage pada lampiran 5 menunjukan koefisien positif sebesar 9.354 dengan tingkat signifikansi 0.012 yang berarti $<0.05$. Dengan demikian $\mathrm{H} 4$ diterima. Leverage berpengaruh terhadap penerimaan opini audit going concern. Hal ini dikarenakan semakin tinggi rasio leverage suatu perusahaan, maka akan semakin menimbulkan keraguan auditor akan kelangsungan hidup perusahaan tersebut, karena sebagian besar dana yang diperoleh perusahaan akan digunakan untuk membiayai hutang. Hasil penelitian ini bertentangan dengan penelitian Pratama dan Badera (2009) namun sesuai dengan hasil penelitian Susanto (2009).

\section{KESIMPULAN DAN SARAN}

\section{Kesimpulan}

Berdasarkan rumusan masalah, tujuan, landasan teori, hipotesis dan hasil pengujian yang dilakukan, maka dapat disimpulkan bahwa prediksi kebangkrutan dan leverage berpengaruh terhadap penerimaan opini audit going concern. Hal ini dikarenakan auditor akan lebih memilih kondisi keuangan perusahaan sebagai bahan pertimbangan dalam menerbitkan opini going concern. Terlepas auditor tersebut berafiliasi dengan The Big 4 maupun tidak, mereka akan mematuhi kode etik dengan bersikap independen dan objektif dalam pekerjaan.

\section{Saran}

Beberapa keterbatasan mempengaruhi hasil penelitian dan perlu menjadi bahan pengembangan pada penelitian selanjutnya. Saran-saran yang dapat disampaikan berdasarkan penelitian ini adalah menambah jumlah periode penelitian dikarenakan jumlah sampel yang mendapatkan opini going concern hanya $15 \%$ dari total observasi. 


\section{DAFTAR PUSTAKA}

Altman, E. 1982. Accounting Implications of Failure Predictions Model. Journal of Accounting, Auditing and Finance. Summer. 4-19

Anwar, Arif Budiman. 2010. Analisis Pengaruh Kinerja Keuangan dan Kualitas Pengungkapan Informasi Terhadap Return Saham. Tesis tidak dipublikasikan. Universitas Indonesia, Jakarta.

BAPEPAM-SE. 2002. Surat Edaran Nomor: Se-02/PM/2002: Pedoman Penyajian dan Pengungkapan Laporan Keuangan Emiten atau Perusahaan Publik Industri Manufaktur.

Fanny, Margaretta dan Sylvia Saputra. 2005. Opini Audit Going Concern: Kajian Berdasarkan Model Prediksi Kebangkrutan, Pertumbuhan Perusahaan, dan Reputasi Kantor Akuntan Publik (Studi pada Emiten Bursa Efek Jakarta). Makalah disampaikan dalam Simposium Nasional Akuntansi VIII. Solo: 1516 September.

Ghozali, Imam. 2005. Aplikasi Analisis Multivariate dengan Program SPSS,Edisi Ketiga, Badan Penerbit Universitas Diponegoro, Semarang.

Hanafi, M Mahmud dan Abdul Halim.2007. Analisis Laporan Keuangan: Edisi Ketiga.UPP STIM YKPN.Yogyakarta.

Ikatan Akuntan Indonesia. 2001. Standar Profesional Akuntan Publik. Jakarta: Salemba Empat.

Junaidi dan Jogiyanto Hartono. 2010. Faktor Nonkeuangan pada Opini Going Concern. Makalah disampaikan dalam Simposium Nasional Akuntansi XIII. Purwokerto: 13-15 Oktober.

Keputusan Menteri Keuangan Nomor: 17/PMK.01/2008 Tentang Jasa Akuntan Publik.

Lennox, Clive S. 2002. Going concern opinions in Failing Companies: Auditor Independence and Opinion Shopping. Working Paper. Available at: http://papers.ssrn.com/so13/papers.cfm?abstarct_id=240468.

Pratama, Arry dan I Dewa Nyoman Badera. 2009. Opini Audit Going Concern: Kajian Berdasarkan Model Prediksi Kebangkrutan, Pertumbuhan Perusahan, Leverage dan Reputasi Auditor. Jurnal Akuntansi dan Bisnis Vol.4, No.2 Juli 2009.

Ramadhani, Ayu Suci dan Niki Lukviarman. 2009. Perbandingan Analisis Prediksi Kebangkrutan Menggunakan Model Altman Pertama, Altman Revisi, dan Altman Modifikasi Dengan Ukuran dan Umur Perusahaan Sebagai Variabel Penjelas (Studi Pada Perusahaan Manufaktur Yang Terdaftar Di Bursa Efek Indonesia). Jurnal siasat Bisnis Vol. 13: Hal 15-28.

Santosa, Arga Fajar dan Linda K Wedari. 2007. Analisis Faktor yang Mempengaruhi Kecenderungan Penerimaan Opini Audit Going Concern. JAAI, Vol. 11. No. 2, Desember 2007: 141-158. 
Sari, Dian Mustika. 2011. Faktor-faktor Yang Mempengaruhi Auditor Dalam Memberikan Opini Going Concern. Skripsi tidak dipublikasikan. Universitas Diponegoro, Semarang.

Setyarno, Eko Budi, Indira Januarti dan Faisal. 2006. Pengaruh Kualitas Audit, Kondisi Keuangan Perusahaan, Opini audit Tahun Sebelumnya, Pertumbuhan Perusahaan terhadap Opini Audit Going Concern. SNA IX Padang, h 1-25

Susanto, Yulius Kurnia. 2010. Faktor-faktor Yang Mempengaruhi Penerimaan Opini Audit Going Concern Pada Perusahaan Publik Sektor Manufaktur. Jurnal Bisnis dan Akuntansi, Vol. 11, No.3 Desember 2009: 155-173

Widyantari, Putri. 2011.Opini Audit Going Concern Dan Faktor-faktor yang Memengaruhi: Studi Pada Perusahaan Manufaktur di Bursa Efek Indonesia. Tesis tidak dipublikasikan. Universitas Udayana, Denpasar. 


\section{LAMPIRAN-LAMPIRAN}

\section{LAMPIRAN 1}

\begin{tabular}{rlrr}
\hline No & \multicolumn{1}{c}{ Kriteria } & $\begin{array}{c}\text { Jumlah } \\
\text { Pelanggaran } \\
\text { Kriteria }\end{array}$ & Observasi \\
\hline 1 & Total Perusahaan manufaktur yang terdaftar di & & 393 \\
& BEI pada tahun 2009-2011=131 & 64 & 329 \\
2 & Data tersedia. & 32 & 297 \\
3 & Menerbitkat Laporan Keuangan dalam rupiah. & 36 & 261 \\
4 & Terdapat Catatan Atas Laporan Keuangan. & 24 & 237 \\
5 & Terdapat Laporan Auditor Independen. & & $\mathbf{2 3 7}$ \\
\hline
\end{tabular}

\section{LAMPIRAN 2}

Descriptive Statistics

\begin{tabular}{lcrrrr} 
& & Minimum & Maximum & Mean & \multicolumn{2}{c}{ Std. Deviation } \\
\hline Opini & 229 & .00 & 1.00 & .1528 & .36062 \\
Reputasi & 229 & .00 & 1.00 & .4236 & .49521 \\
Disclosure & 229 & .36 & .81 & .5764 & .08668 \\
Leverage & 229 & .05 & 3.21 & .6264 & .59067 \\
Zscore & 229 & -9.67 & 24.87 & 3.6979 & 4.94169 \\
Valid N (listwise) & 229 & & & & \\
\end{tabular}

\section{LAMPIRAN 3}

Hosmer and Lemeshow Test

\begin{tabular}{llllr}
\hline Step & Chi-square & & df & Sig. \\
1 & & & 8 & \\
& & .319 & & 1.000
\end{tabular}




\section{LAMPIRAN 4}

\section{-22 LL Awal (Block Number = 0)}

\begin{tabular}{lrrr}
\hline & & \multicolumn{2}{c}{ Iteration History $^{\mathbf{a}, \mathbf{b}, \mathbf{c}}$} \\
Iteration & & -2 Loefficients \\
\hline Step 0 & 1 & 199.190 & -1.389 \\
& 2 & 195.870 & -1.681 \\
& 3 & 195.841 & -1.712 \\
& 4 & 195.841 & -1.713
\end{tabular}

a. Constant is included in the model.

b. Initial -2 Log Likelihood: 195.841

c. Estimation terminated at iteration number 4

because parameter estimates changed by less than .001 .

\section{LL Akhir (Block Number = 1)}

\begin{tabular}{lrrr} 
& \multicolumn{3}{c}{ Model Summary } \\
& & & \\
& & Cox \& Snell R & Nagelkerke R \\
Step & -2 Log likelihood & Square & \multicolumn{2}{c}{ Square } \\
\hline 1 & $20.733^{\mathrm{a}}$ & .535 & .930
\end{tabular}

a. Estimation terminated at iteration number 11 because parameter estimates changed by less than .001 .

\section{LAMPIRAN 5}

\section{Classification Table ${ }^{\mathrm{a}}$}

Predicted

\begin{tabular}{|c|c|c|c|c|c|}
\hline & & & Op & & Percentage \\
\hline & Obser & & NGCO & GCO & Correct \\
\hline Step 1 & Opini & NGCO & 192 & 2 & 99.0 \\
\hline & & GCO & 3 & 32 & 91.4 \\
\hline & Overa & Percenta & & & 97.8 \\
\hline
\end{tabular}




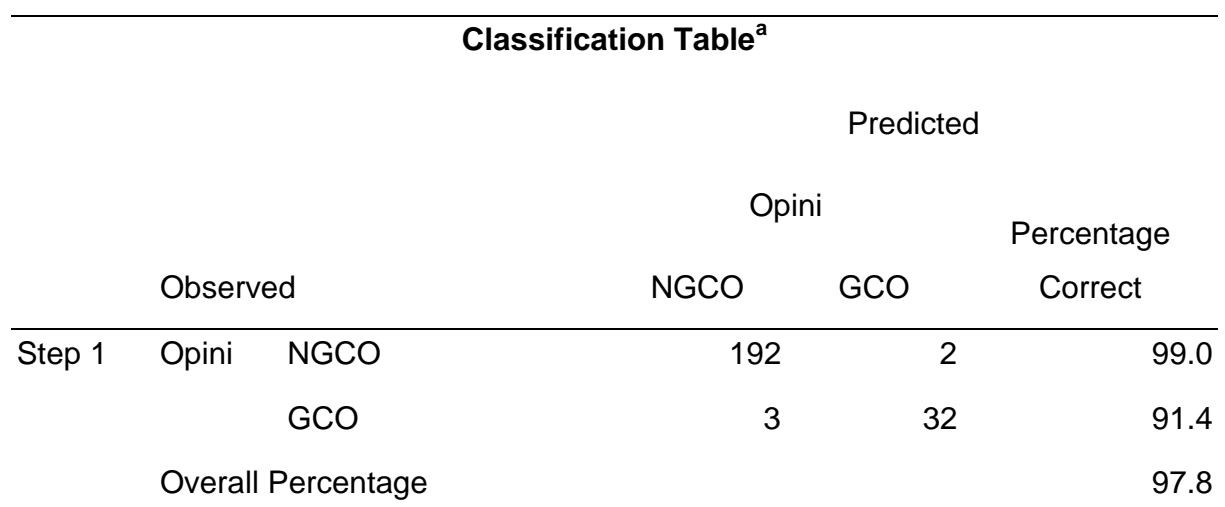

a. The cut value is .500

\section{LAMPIRAN 6}

\begin{tabular}{|c|c|c|c|c|c|c|c|}
\hline \multicolumn{8}{|c|}{ Variables in the Equation } \\
\hline & & B & S.E. & Wald & df & Sig. & $\operatorname{Exp}(B)$ \\
\hline \multirow{5}{*}{ Step $1^{a}$} & Reputasi & 3.254 & 2.014 & 2.612 & 1 & .106 & 25.906 \\
\hline & Zscore & -2.495 & .925 & 7.277 & 1 & .007 & .083 \\
\hline & Disclosure & 10.011 & 6.981 & 2.057 & 1 & .152 & 22278.433 \\
\hline & Leverage & 9.354 & 3.725 & 6.307 & 1 & .012 & 11545.980 \\
\hline & Constant & -14.209 & 6.054 & 5.508 & 1 & .019 & .000 \\
\hline
\end{tabular}

a. Variable(s) entered on step 1: Reputasi, Zscore, Disclosure, Leverage. 